\title{
Implications of global warming and urban land use change on Flooding in Europe
}

\author{
L. Feyen, J.I. Barredo, R. Dankers
}

Institute for Environment and Sustainability, DG JRC, European Commission

(E-mail: luc.feyen@jrc.it; jose.barredo@jrc.it; rutger.dankers@jrc.it)

\begin{abstract}
This paper presents an integrated methodology to assess the implications of climate change and urban land use changes for future flood damage in Europe. To determine changes in flood hazard due to global warming, high resolution regional climate simulations from the HIRHAM model were used to drive the hydrological model LISFLOOD. Calculated flood inundation extents and depths were transformed into direct monetary damage using flood depth-damage functions and land use information. For each country expected annual damages (EAD) were calculated from the damage-probability functions. To account for flood protection the damage-probability functions were truncated at design return periods based on the country GDP. Results indicate that, under the A2 scenario, most countries in Europe will see an increase in EAD in the coming century. For EU27 as a whole, current EAD of 6.5 billion $€$ is projected to reach 18 billion $€$ (in constant prices of 2006) by the end of this century under the A2 scenario. For the region of Madrid, future developments in urban land use were simulated with the cellular automata (CA)-based model MOLAND. Damage calculations based on the future land use patterns for this region show that the effect of increased exposure due to urban expansion by far outweighs the effect of climate change.
\end{abstract}

Keywords

Floods; damage; climate change; urban land use change

\section{INTRODUCTION}

Floods are the most common natural disaster in Europe. Over the last decades, the costs of floods have exhibited a rapid increase (Munich Re, 2005; Barredo, 2007). Part of the observed upward trend in flood damage can be attributed to socio-economic factors, such as the increase in population and wealth in flood-prone areas, as well as to changes in the terrestrial system, such as urbanisation and deforestation, that have lead to the loss of wetlands and natural floodplain storage (e.g. via dike construction, river straightening and floodplain sedimentation). Changes in climate may also have played a role. However, the conclusion of a positive contribution of climate change is premature (Mudelsee et al., 2003; Kundzewicz et al., 2005), partly because of the inherent difficulties and uncertainties in detecting trends in extreme river flows amidst strong natural variability.

Recent advances in climate modelling, however, suggest that climate change will likely play a role in the future. For the coming decades, it is projected that global warming will intensify the hydrological cycle and increase the magnitude and frequency of intense precipitation events in most parts of Europe, especially in the central and northern parts (Christensen and Christensen, 2003; Semmler and Jacob, 2004). This will likely contribute to an increase in flood hazard triggered by intense rain, particularly the occurrence of flash floods. Flood hazard may also rise during wetter and warmer winters, with increasingly more frequent rain and less frequent snow. On the other hand, ice-jam and early spring snowmelt floods are likely to reduce because of warming (Kundzewicz et al., 2006).

In recent years, many climate change impact studies have appeared in the literature. The majority of impact studies on the hydrological cycle have focused on water resources, average flow conditions, 
and changes in seasonal runoff, in part because long-term average values are generally considered the more reliable outputs of climate and large-scale hydrological models. Regional assessments of climate change impacts on flood hazard have been relatively rare. Most studies have adopted a basin-scale approach (e.g., Booij, 2005; Kay et al., 2006), because floods are often determined by small to meso-scale processes. The application of different climate scenarios, hydrological models and the basin-specific characteristics make it difficult to compare the results of the different studies and to draw an overall picture of the effects of climate change on flood hazards at the European scale.

Lehner et al. (2006) made an integrated European assessment of changes in flood risk due to climate change. They used climate data from the ECHAM4 and HadCM3 General Circulation Models (GCMs), based on a scenario that is largely consistent with the no-policy IPCC-IS92a scenario, in combination with the global integrated water model WaterGAP to define large critical regions of increases in flood and drought hazards. The monthly averaged GCM output was disaggregated in space and time to the temporal scale (daily) and (coarse) spatial scale ( 0.5 degrees) of WaterGAP. In the climate signal, only long-term trends and changes in seasonal climate were taken into account, while changes in short-range variability were neglected. These assumptions do not allow a proper evaluation of changes in climatic extremes, which may show a very different pattern compared to the average changes in climate, and constrain the reliability of the results with respect to changes in flood hazard. More recently, Dankers and Feyen (2008) evaluated changes in flood hazard in Europe using very high resolution climate data from the HIRHAM regional climate model driven by the SRES A2 greenhouse gas emission scenario. Their results confirm an increase in flood hazard for many European rivers by the end of this century, but in certain regions, notably in the northeast and parts of central and southern Europe, a considerable decrease in flood hazard was found.

Monetary assessments of the impacts of climate change in Europe have been poorly covered to date. Hall et al. (2005) presented a national-scale assessment of current and future coastal and river flood risk in England and Wales. Their analysis uses information on flood defences (including probability of failure), land use, impact (depth-damage and population data) together with datasets on floodplain extent and topography. No changes in land use were considered. Results indicated an up to 20 -fold increase in real terms economic risk by the 2080 s for the scenario with the highest economic growth. No studies have yet appeared in the literature with a European coverage.

The aim of this paper is to estimate future changes in expected annual damage from floods at European scale, taking into account flood protection measurements. The flood risk analysis described in this paper builds upon the flood hazard assessment of Dankers and Feyen (2008). For a case study around Madrid, we also simulate future developments in urban land use and assess the importance of changes in exposed property against climate-induced changes in flood hazard itself.

\section{METHODOLOGY TO ASSESS CURRENT AND FUTURE RISK}

In this paper we present an integrated methodology to assess the impact of global warming and urban land use change on flood risk in Europe. The framework is presented in Figure 1. In the remainder of this section, the different steps are explained in more detail. 


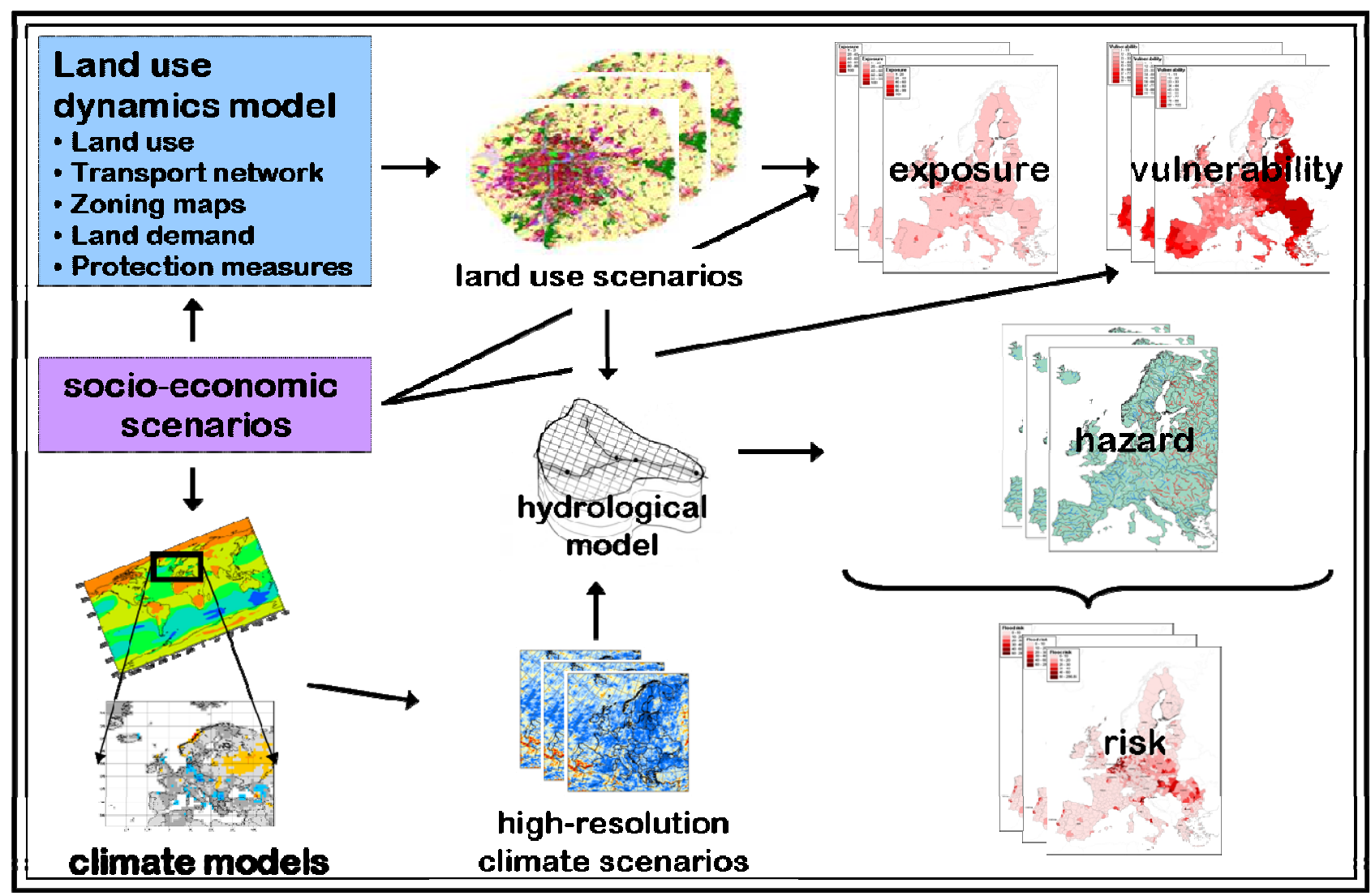

Figure 1: Integrated framework to assess current and future flood risk in Europe.

\section{Flood hazard assessment}

Flood generation is a highly non-linear process that depends on factors such as the intensity, volume and timing of precipitation, antecedent conditions of the river basin (e.g. soil wetness, snow or ice cover), river morphology, land use, and flood control measures (e.g. reservoirs, dikes). Because of the small to meso-scale character of these factors, the assessment of climate change impacts on flood hazard is typically carried out at the catchment scale by means of one-way coupling of climate model output with a hydrological model.

In recent years, the horizontal resolution of RCM simulations has increased considerably and now approaches a level that allows capturing fine-scale climatic structures induced by complex topography or land use patterns, which is essential for flood hazard assessment. In this paper we use data from a recent experiment with the regional climate model HIRHAM (Christensen et al., 1996) run with a horizontal resolution of $12 \mathrm{~km}$, much higher than the 25 or $50 \mathrm{~km}$ typically used in RCM simulations. This experiment has been conducted within the framework of the PRUDENCE project (Prediction of Regional scenarios and Uncertainties for Defining EuropeaN Climate change risks and Effects; Christensen et al., 2007). The simulations consist of two 30-year time slices: a control run with a greenhouse gas forcing corresponding to 1961-1990, and a scenario run corresponding to 2071-2100 according to the A2 scenario of the Intergovernmental Panel on Climate Change (IPCC) (Nakicenovic and Swart, 2000). In the control run, the lateral boundaries were derived from the HadAM3H high-resolution global atmosphere model, which itself had been forced by lowresolution observed sea surface temperature (SST) and sea-ice extent. The climate change signal in SST and sea-ice extent for future conditions came from the global coupled atmosphere-ocean model HadCM3 (Gordon et al., 2000; Pope et al., 2000). Simulation of extreme precipitation by HIRHAM has previously been described by Christensen and Christensen (2004) and May (2007).

The HIRHAM simulations of temperature, precipitation, solar and thermal radiation, humidity and 
wind speed data were used to drive the hydrological model LISFLOOD (van der Knijff et al., 2008). This model has been developed for operational flood forecasting at European scale and is a combination of a grid-based water balance model and a 1-dimensional hydrodynamic channel flow routing model. Since it is spatially distributed, the model can take account of the spatial variation in land use, soil properties and precipitation. The current, European-wide set-up uses a $5 \mathrm{~km}$ grid and input parameters on soil and land use were derived from European databases. The model parameters that control infiltration, snowmelt, overland and river flow, as well as residence times in the soil and subsurface reservoirs, were estimated by calibrating against historical records of river discharge in 231 catchments and subcatchments. For catchments where discharge measurements were not available simple regionalization techniques (regional averages) were applied to obtain the model parameters. In the current simulations the HIRHAM data were re-gridded to the $5 \mathrm{~km}$ grid scale of LISFLOOD without any further downscaling or altitude correction. This means that any bias in (especially) the precipitation fields will directly influence the LISFLOOD simulations. However, at European scale there is presently no high-quality precipitation dataset available with sufficient observation length and spatial resolution that would allow a proper downscaling of the 12-km HIRHAM data (Dankers and Feyen, 2008).

To estimate the probability of extreme discharge levels, a Gumbel distribution was fitted to the annual maximum values in every river grid cell, whereby the location and scale parameter were estimated using Maximum Likelihood Estimation (MLE), following Gilleland and Katz (2005). From the fitted Gumbel distributions of extreme discharges, return levels were derived for every river pixel for return periods of $2,5,10,20,50,100,250$ and 500 years. For validation the simulated extreme discharges from the LISFLOOD model run driven by the control climate were compared with observations at 209 gauging stations across Europe for which long enough daily data (30 years covering 1960-90 or 1970-2000) were available. The LISFLOOD model, when being driven by the HIRHAM data, was able to reproduce both mean and high discharge levels across Europe reasonably well, considering that most of these rivers are regulated (see Dynesius and Nilsson, 1994). Over all stations the performance with respect to reproducing yearly maximum flows was satisfactory $\left(r^{2}=0.90\right)$ (for more details see Dankers and Feyen, 2008).

\section{Flood risk assessment}

Flood risk assessment requires the integration of the physical impact results (flood inundation extent and depth) with information on flood defences, land use, and impact (depth-damage functions). Based on a high-resolution $(100 \mathrm{~m})$ digital elevation model, the simulated stream water levels for the control and scenario climate were transferred into flooded areas and inundation water depths, and changes in flooded areas and water depths were determined for each return period. In this step, flood protection measures are not taken into account. Using country specific flood depthdamage functions and land use information from CORINE Land Cover 2000 (EEA, 2000), direct damage estimates are obtained for each return period. This results in a damage-probability function under present and future climate. In reality, of course, most countries have flood defence measures up to a certain design flood to prevent areas from flooding. To account for flood protection the damage-probability function is therefore truncated at the corresponding design return period. In this way, damages from floods with lower return periods are discarded. The integral of the remaining part of the function corresponds to the expected annual damage (EAD), a measure of the expected yearly loss due to flooding taking into account flood protection measures.

The approach used is based on direct estimated potential flood damage caused by water depths on land use typologies. Other factors that might contribute to the increase of losses are not included in this study: flood velocity, building characteristics, content of sediment in water, and estimated of indirect economic losses. It is also important to note that in the calculation of future flood risk we did not account for any projected growth in exposed values, hence all damages are based on current 
exposed values.

\section{Flood risk assessment and urban land use changes}

To evaluate the effect of urban land use changes on flood damages a land use scenario consistent with the SRES A2 emission scenario was developed for the region of Madrid (Barredo and Gómez Delgado, 2008). The region covers an area of about $10,000 \mathrm{~km}^{2}$ and includes 340 municipalities of the Madrid autonomous Community and other municipalities beyond it representing the functional region of Madrid. It is considered to be one of the hot-spots in urban development in the EU (EEA, 2005, Ludlow et al., 2006). A number of interlinked socio-economic factors, such as social demand for housing and increased mobility, have resulted in an intense de-centralisation of population and economic activity in the region in the last decades (López de Lucio, 2003). As a consequence, the territory of Madrid has been developing towards a sprawled-like region, a process that has taken place within a weak spatial planning framework that is common to a large number of European urban areas (López de Lucio, 2003; Fernández-Galiano, 2006).

For modelling urban land use development the cellular automata (CA)-based model MOLAND (White et al. 1999, Barredo et al. 2003, Barredo et al. 2004) was used. At each time step, the model calculates for each cell a vector of land use transition probabilities based on a number of factors that drive land use dynamics, such as accessibility, land use zoning regulations, suitability and existing land use patterns. In a calibration phase, a set of transition rules is derived based on historical land use trends. The model was calibrated using land use information from CORINE and transport network layers from the TELEATLAS database for Europe for the period 1990 to 2000. A reasonably good agreement was obtained between the observed and simulated map for 2000 (for more details see Barredo and Gómez Delgado, 2008).

When modelling future land use, the assumptions defined in the calibration phase are modified based on the meta-narrative description of the SRES A2 storyline describing the socio-economic and political conditions that drive future land use change. For Europe and the Madrid region the set of drivers that characterize the A2 scenario are detailed in Table 1. These drivers were fed into the model and land use was modelled at a horizontal resolution of $100 \mathrm{~m}$. Due to some computational constraints, land use was only modelled until 2040, and it was assumed to remain stable hereafter. This is not fully consistent with the 2070-2100 period for which future flood hazard was estimated, and may result in an underestimation of flood damages when accounting for urban land use changes.

Table 1: Qualitative description of meta-narrative for A2 scenario used in studies of urban land use simulation of climate change scenarios.

\begin{tabular}{clc}
\hline $\begin{array}{c}\text { SRES } \\
\text { scenario }\end{array}$ & \multicolumn{1}{c}{$\begin{array}{c}\text { Madrid region } \\
\text { (Barredo and Gómez Delgado, } \\
\text { 2008) }\end{array}$} & $\begin{array}{c}\text { Europe (Reginster and } \\
\text { Rounsevell, 2006) }\end{array}$ \\
\hline A2 & - Rapid urban growth & - Significant increase in the \\
& - Increasing share of low density & extension of built-up areas \\
& areas & - Small/medium size cities \\
& - Low infilling & expand most rapidly \\
& - Diffuse suburbanisation & - Suburbanisation and counter \\
& - Loose spatial planning policy & urbanisation \\
& - Increasing population & - Increasing population \\
\hline
\end{tabular}

Figure 2 shows urban land use in the Madrid region for 1990 and 2000 (both CORINE) and for 
2040 under the A2 scenario. Rapid urban growth with little spatial planning policy in this scenario leads to diffuse and periurban developments around the core city, with a relevant influence of the road transport network in the distribution of new urban nuclei and growth of urban areas.
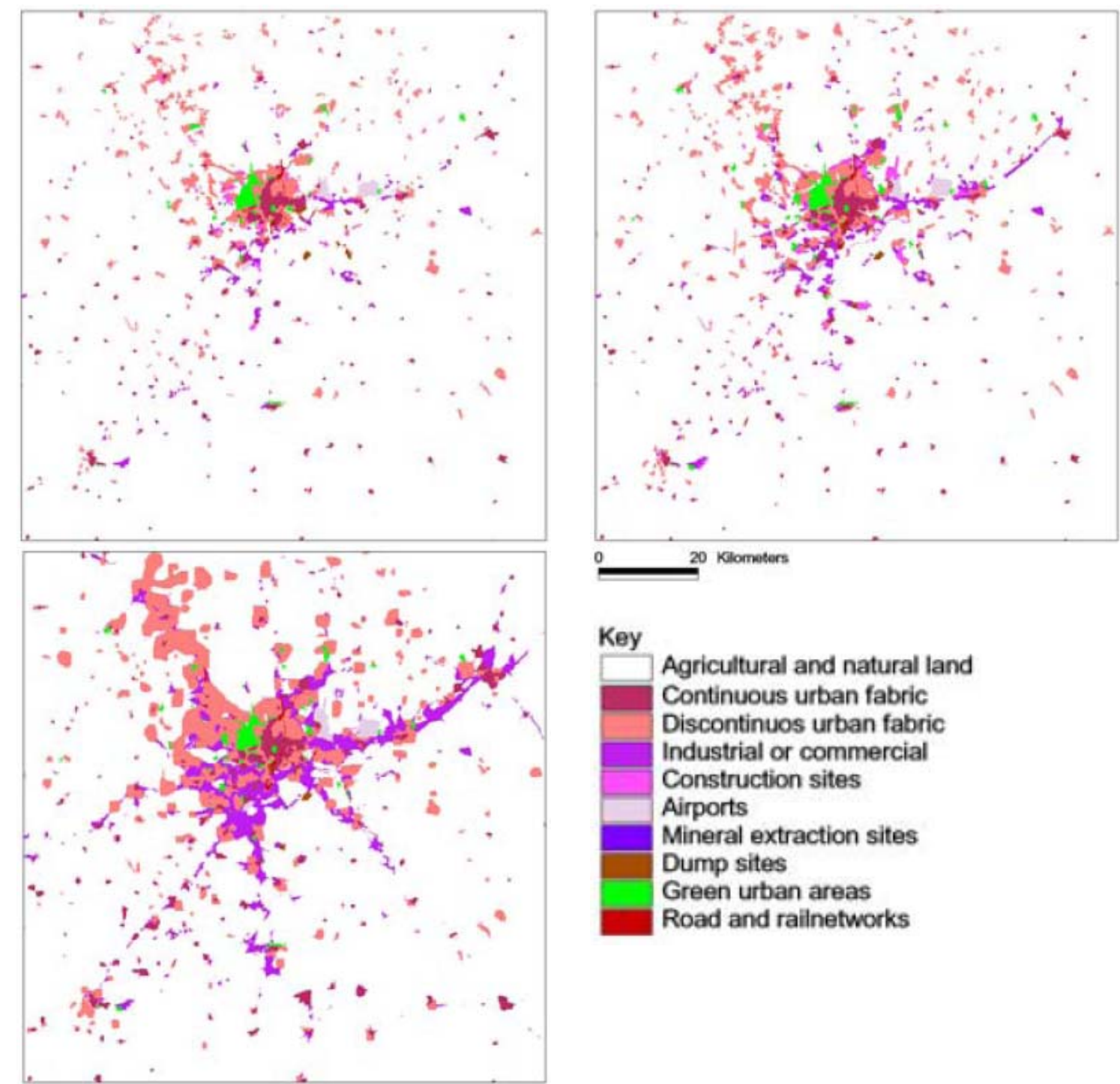

Figure 2: Urban land use in the Madrid region: (top left) CORINE 1990, (top right) CORINE 2000; (bottom left) land use 2040 under A2 scenario (rapid urban growth).

Land use can affect flood damages in two ways. Firstly, land use changes that invoke increasing population and wealth in flood-prone areas directly affect the exposed assets in flood prone regions. Secondly, landscape changes within the catchment, such as urbanisation and deforestation, lead to the loss of wetlands and natural floodplain storage, and may increase flood hazard. In this work, only the first aspect is considered, as it is considered to have more impact on flood damages. This implies that in evaluating the impact of urban land use changes, the calculation of flood hazard is based on static land use in the contributing catchment area.

\section{RESULTS AND DISCUSSION}

\section{Changes in flood hazard in Europe due to climate change}

Figure 3 shows the change in the 100-year return level of river discharge between the scenario and control run. Although the estimation of discharge levels with high return periods is subject to large uncertainties, the patterns of change between the control and scenario period that can be seen in 
Figure 3 are comparable to the changes for shorter return intervals or even for the mean annual maximum discharge (Dankers and Feyen, 2008).

The 100-year return discharge levels decrease strongly in the north-eastern part of the continent (i.e. Finland, northern Russia and part of the Baltic States). Decreases can also be seen along the Norwegian coast and, to a varying degree, in central Europe and the southern half of the Iberian Peninsula. Strong increases in the 100-year flood level are simulated across much of western and central Europe, including parts of the Balkan, northern Italy and locally also in Sweden and southern Norway. The decrease in the magnitude of the 100-year flood in north-eastern Europe can be attributed to a decrease in snow accumulation. In this area the natural flow regime of the rivers is dominated by a discharge peak in spring due to melting of the winter snow pack. Despite an increase in winter precipitation over much of northern Europe, higher temperatures in winter and spring result in a decrease in the annual snow mass of $40 \%$ or more, as well as a shortening of the snow season of locally more than two months. As a consequence the spring snowmelt flood is less severe, which is reflected in the reduced estimate of the 100-year return level over the entire year. In summer and autumn, however, the magnitude of extreme discharges may well increase.

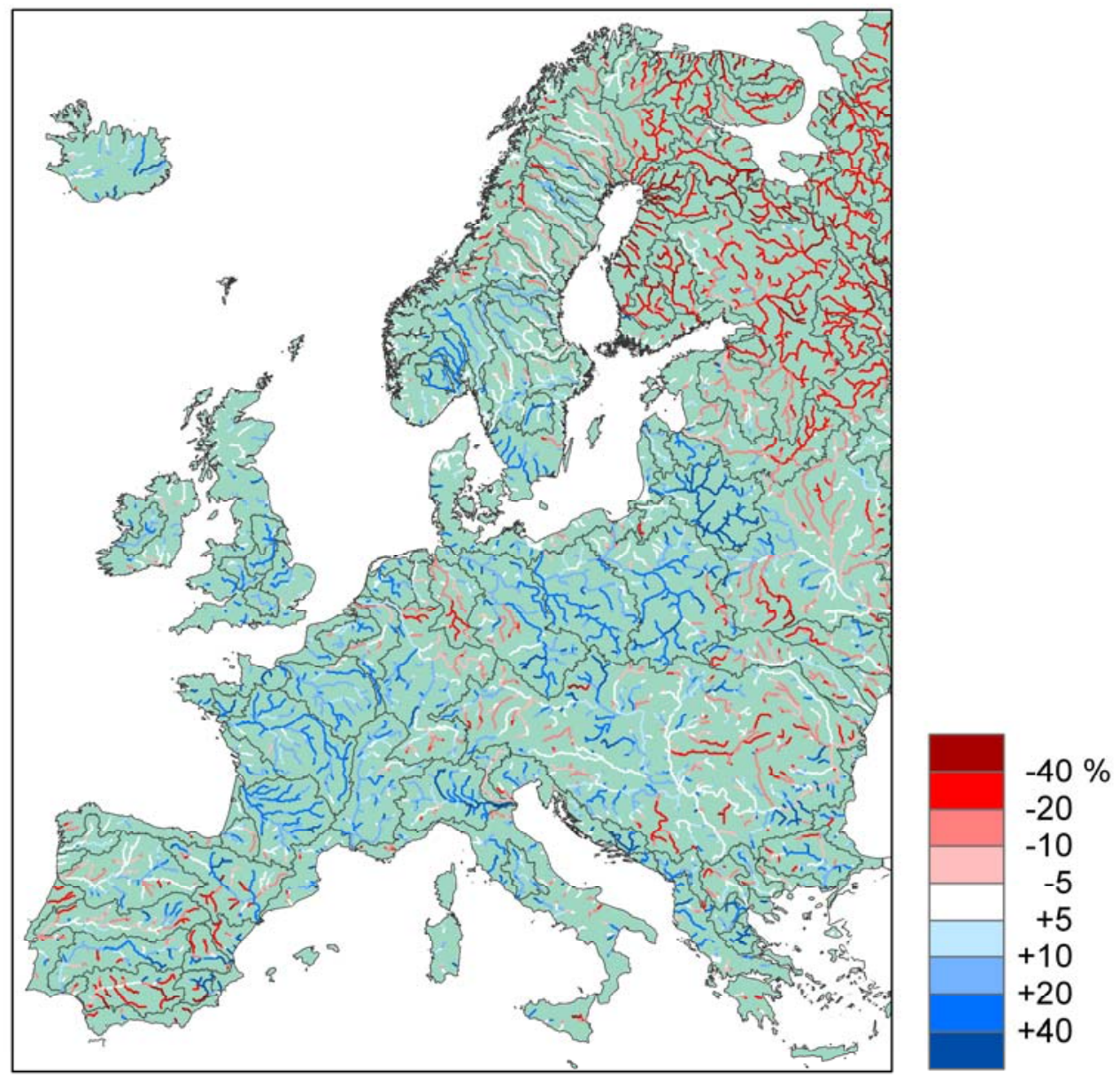

Figure 3: Relative change in 100-year return level of river discharge between scenario (2071-2100) and control period (1961-1990) as estimated from the Gumbel distribution fitted to the annual maximum discharges. Simulations with LISFLOOD driven by HIRHAM - HadAM3H/ HadCM3 and IPCC SRES scenario A2. Shown here are only rivers with an upstream area of $1000 \mathrm{~km}^{2}$ or more (Dankers and Feyen, 2008).

\section{Changes in flood risk in Europe due to climate change}

Figure 4 shows the relative change in 100-year flood damage (averaged over NUTS 2 level) 
between the control climate and the climate under the A2 scenario. The pattern in flood damage changes in Europe reflects the pattern observed in the changes in flood hazard, with strong increases across much of western and central Europe, including Italy and eastern parts of Spain and locally also in Greece and southern Sweden. The strongest decrease in flood damage is observed in northeastern Europe. Similar patterns of change in damage were observed for other return periods.

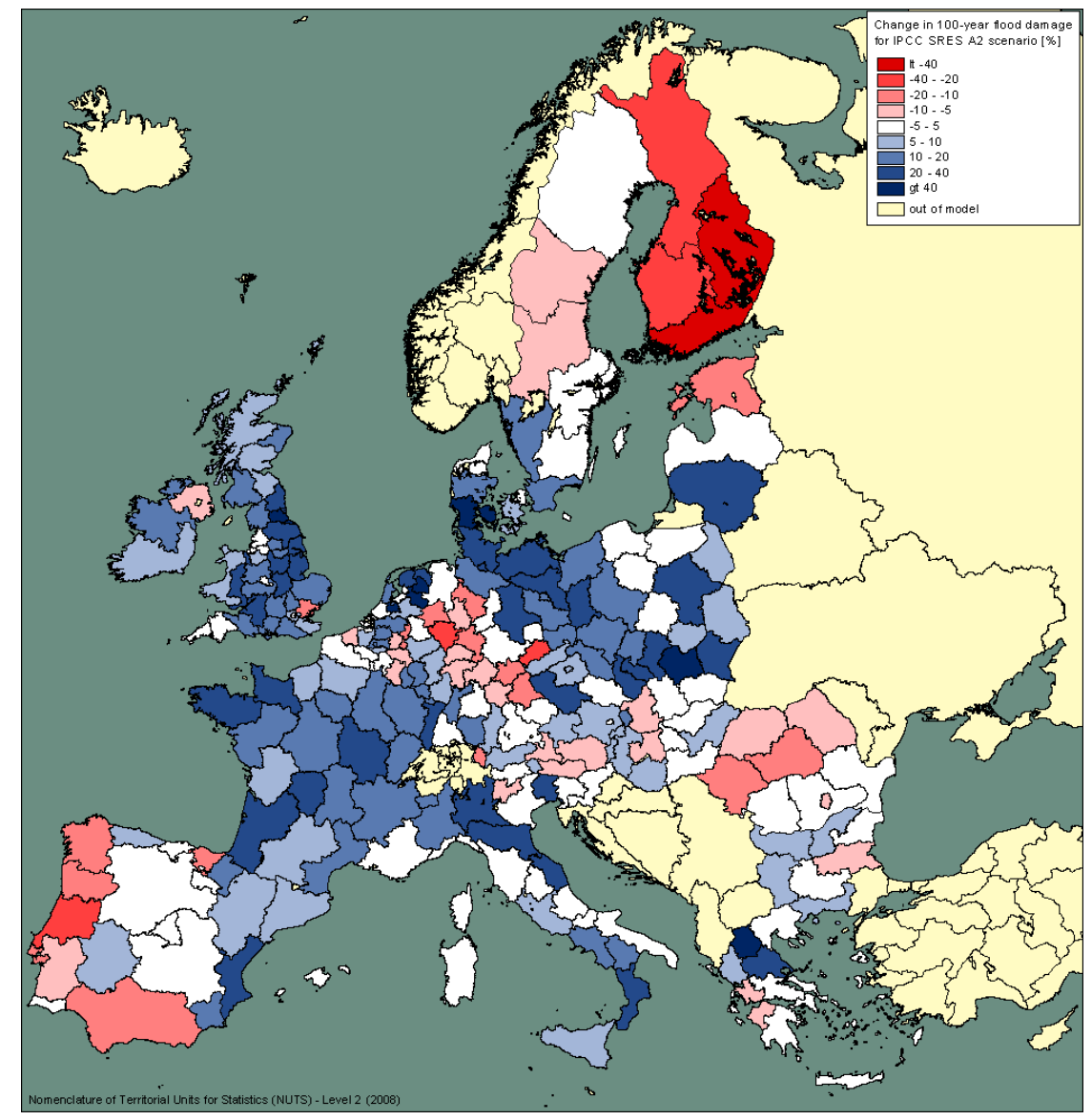

Figure 4: Relative change in 100-year flood damage (averaged over NUTS 2 level) between scenario (2071-2100) and control period (1961-1990). Simulations with LISFLOOD driven by HIRHAM - HadAM3H/ HadCM3 based on IPCC SRES scenario A2.

Expected annual damages (EAD) have been calculated from the damage-probability functions. Since data about flood protection levels, including their probability of failure, hardly exist at the national or European level, we assumed for illustrative purposes different levels of flood protection for EU countries based on their GDP (see Table 2). For countries with a GDP larger than 110\% of the average EU27 GDP we assumed protection up to 100-year flood events (dark gray in Table 2). For countries with a GDP between 55 and $110 \%$ of the average EU27 GDP (medium gray in Table 2) a 75 -year return level protection was imposed. For countries with a GDP lower than $55 \%$ of the average EU27 GDP (light gray in Table 2) the damage probability functions were cut-off at the 50year return level. No adaptation to increasing flood levels is taken into account. Therefore, the same levels of protection in terms of design discharge were imposed for the control and scenario period. To this end, design discharge levels imposed for the control period (reflecting current levels of protection) were converted into the corresponding return periods in the future climate (which are not necessarily the same as for the control period). These were then used to appropriately truncate the damage-probability function.

Country-averaged values of expected annual damages are presented in Table 2 for the control and 
scenario period. Results indicate that, under the A2 scenario, most countries in Europe will see an increase in EAD in the coming century, assuming the assumed levels of protection remain fixed, with increases that vary between 40 up to $800 \%$, depending on the country. Only a few countries will see a reduction in EAD, which is most pronounce for Finland. For EU27 as a whole, current EAD of 6.5 billion $€$ is projected to reach 18 billion $€$ (in constant prices of 2006) by the end of this century under the A2 scenario. We would like to stress again that the estimates of future flood losses are based on current exposed values, hence no growth in exposed values is taken into account.

Table 2: Country-averaged expected annual damage (EAD) in $€$ for control and future climate (based on SRES A2 scenario). Different levels of flood protection are imposed based on country GDP (dark gray: 100 year return level protection; medium gray: 75 year return level protection; light gray: 50 year return level protection).

\begin{tabular}{cccc}
\hline Country & EAD ctrl $(€)$ & EAD scen $(€)$ & scen/ctrl \\
\hline AT & $2.4 \mathrm{E}+08$ & $4.1 \mathrm{E}+08$ & 1.73 \\
BE & $1.6 \mathrm{E}+08$ & $2.7 \mathrm{E}+08$ & 1.72 \\
DK & $1.2 \mathrm{E}+07$ & $9.3 \mathrm{E}+07$ & 7.85 \\
FI & $3.0 \mathrm{E}+08$ & $4.5 \mathrm{E}+07$ & 0.15 \\
FR & $1.0 \mathrm{E}+09$ & $4.0 \mathrm{E}+09$ & 3.93 \\
DE & $6.8 \mathrm{E}+08$ & $1.4 \mathrm{E}+09$ & 2.09 \\
IE & $2.3 \mathrm{E}+07$ & $5.4 \mathrm{E}+07$ & 2.33 \\
LU & $1.1 \mathrm{E}+07$ & $3.9 \mathrm{E}+07$ & 3.59 \\
NL & $3.6 \mathrm{E}+08$ & $9.9 \mathrm{E}+08$ & 2.79 \\
SE & $1.3 \mathrm{E}+08$ & $2.5 \mathrm{E}+08$ & 1.93 \\
UK & $7.8 \mathrm{E}+08$ & $3.6 \mathrm{E}+09$ & 4.61 \\
CY & $0.0 \mathrm{E}+00$ & $0.0 \mathrm{E}+00$ & 1.00 \\
CZ & $2.7 \mathrm{E}+08$ & $9.4 \mathrm{E}+08$ & 3.53 \\
GR & $4.9 \mathrm{E}+07$ & $2.3 \mathrm{E}+08$ & 4.69 \\
HU & $3.5 \mathrm{E}+08$ & $7.7 \mathrm{E}+08$ & 2.19 \\
IT & $8.9 \mathrm{E}+08$ & $2.5 \mathrm{E}+09$ & 2.80 \\
MT & $0.0 \mathrm{E}+00$ & $0.0 \mathrm{E}+00$ & 1.00 \\
PT & $2.5 \mathrm{E}+07$ & $9.9 \mathrm{E}+06$ & 0.39 \\
SK & $1.4 \mathrm{E}+08$ & $2.5 \mathrm{E}+08$ & 1.82 \\
SI & $4.8 \mathrm{E}+07$ & $4.0 \mathrm{E}+07$ & 0.83 \\
ES & $2.8 \mathrm{E}+08$ & $5.8 \mathrm{E}+08$ & 2.02 \\
BG & $5.7 \mathrm{E}+07$ & $1.3 \mathrm{E}+08$ & 2.21 \\
EE & $8.3 \mathrm{E}+06$ & $6.4 \mathrm{E}+06$ & 0.77 \\
LV & $2.8 \mathrm{E}+07$ & $3.9 \mathrm{E}+07$ & 1.39 \\
LT & $2.6 \mathrm{E}+07$ & $1.2 \mathrm{E}+08$ & 4.65 \\
PL & $4.3 \mathrm{E}+08$ & $1.1 \mathrm{E}+09$ & 2.66 \\
RO & $2.2 \mathrm{E}+08$ & $1.6 \mathrm{E}+08$ & 0.70 \\
\hline EU27 & $6.5 \mathrm{E}+09$ & $1.8 \mathrm{E}+10$ & 2.77 \\
\hline & & & \\
\hline
\end{tabular}

\section{Changes in flood risk in Madrid region due to climate change and urban land use change}

For the $10,000 \mathrm{~km} 2$ window comprising the Madrid region EAD amounted to 13 million $€$ for the control period. For the scenario period EAD is projected to increase to 23 million $€$ in constant prices of 2006 (increase of 75\%) with static land use. When taking into account urban land use changes in the damage calculations EAD is projected to rise up to 110 million $€$, or an increase of $750 \%$. These results indicate that the effect of increased exposure due to urban expansion by far outweighs the effect of climate change. 


\section{CONCLUSIONS}

Both global warming and urban land use dynamics are expected to considerably affect future flood damages in Europe. We presented an integrated methodology to assess the implications of these two factors for future flood damage in Europe. Changes in flood hazard for the SRES A2 scenario were obtained by combining high resolution regional climate simulations from the HIRHAM model with a the hydrological model LISFLOOD setup for all catchments in Europe. Calculated flood inundation extents and depths were transformed into direct monetary damage using flood depthdamage functions and land use information. For each country expected annual damages (EAD) were calculated from the damage-probability functions. To account for flood protection the damageprobability functions were truncated at design return periods based on the country GDP. Results indicate that, under the A2 scenario, most countries in Europe will see an increase in EAD in the coming century. For EU27 as a whole, current EAD of 6.5 billion $€$ is projected to reach 18 billion $€$ (in constant prices of 2006) by the end of this century under the A2 scenario. For the region of Madrid, future developments in urban land use were simulated with the cellular automata (CA)based model MOLAND. Damage calculations based on the future land use patterns for this region show that the effect of increased exposure due to urban expansion by far outweighs the effect of climate change.

It is important to note that the results in this work are based on the SRES A2 greenhouse emission scenario, and that climate simulations from only one regional model driven by one General Circulation Model have been considered. Simulations based on other greenhouse gas emission scenarios or with other driving GCMs may deviate from those described here. An ensemble approach considering multiple driving models for different emission scenarios should provide a more robust estimate of future flood damages.

\section{REFERENCES}

ABI (2005) Financial risks of climate change. June 2005 Summary Report.

Barredo J.I., Kasanko M., McCormick N., Lavalle C. (2003) Modelling dynamic spatial processes: simulation of urban future scenarios through cellular automata. Landscape and Urban Planning, 64, pp 145-160.

Barredo J.I., Demicheli L., Lavalle C., Kasanko M., McCormick N. (2004) Modelling future urban scenarios in developing countries: an application case study in Lagos, Nigeria. Environment and Planning B: Planning and Design, 32, pp 65-84.

Barredo, J.I., 2007. Major flood disasters in Europe: 1950-2005. Natural Hazards, 42, 125-148.

Barredo, J.I., Gómez Delgado M. (2008) Towards a set of IPCC SRES urban land-use scenarios: Modelling urban land-use in the Madrid region. In: M. Paegelow and M.T. Camacho Olmedo (Eds.), Modelling Environmental Dynamics, Springer (in press).

Booij M.J. (2005) Impact of climate change on river flooding assessed with different spatial model resolutions. Journal of Hydrology, 303, 176-198.

Christensen O.B., Christensen J.H. (2003) Severe summertime flooding in Europe, Nature, 421, 805-806.

Christensen, O.B., and J.H. Christensen (2004) Intensification of extreme European summer precipitation in a warmer climate, Global Planet. Change, 44, 107-117.

Christensen, J.H., and O.B. Christensen (2007), A summary of the PRUDENCE model projections of changes in European climate by the end of this century, Climatic Change, 81, 7-30, doi:10.1007/s10584-006-9210-7.

Christensen, J.H., O.B. Christensen, P. Lopez, E. Van Meijgaard, and M. Botzet (1996), The HIRHAM4 regional atmospheric climate model, DMI Scientific Report 96-4, Danish Met. Inst., Copenhagen, Denmark.

Christensen, J.H., T.R. Carter, M. Rummukainen, and G. Amanatidis (2007), Evaluating the 
performance and utility of regional climate models: the PRUDENCE project, Climatic Change, 81, 1-6, doi:10.1007/s10584-006-9211-6.

Dankers, R., L. Feyen (2008) Climate change impact on flood hazard in Europe: An assessment based on high resolution climate simulations, Journal of Geophysical Research, 2007JD009719RR, in press.

Dynesius, M., C. Nilsson (1994) Fragmentation and flow regulation of river systems in the northern third of the world, Science, 266,753-762.

European Environment Agency (2000). The European Topic Centre on Terrestrial Environment: Corine land cover raster database $2000-100 \mathrm{~m}$.

EEA (2005) The European environment - State and outlook 2005. Luxembourg: Office for Official Publications of the European Communities, European Environment Agency.

Fernández-Galiano L. (2006) Paisajes Españoles. Babelia (El País), 22 April, p. 20.

Gilleland, E., R.W. Katz (2005) Extremes Toolkit (extRemes): Weather and Climate Applications of Extreme Value Statistics, tutorial, Univ. Corp. for Atm. Res., Boulder, CO.

Gordon, C., C. Cooper, C.A. Senior, H.T. Banks, J.M. Gregory, T.C. Johns, J.F.B. Mitchell, and R.A. Wood (2000) The simulation of SST, sea ice extents and ocean heat transports in a version of the Hadley Centre coupled model without flux adjustments, Climate Dynamics, 16, 147-168. doi: $10.1007 / \mathrm{s} 003820050010$.

Hall J.W., Sayers P.B., Dawson R.J. (2005) National-scale assessment of current and future flood risk in England and Wales. Natural Hazards, 36, 147-164.

Kay A.L, Jones R.G., Reynard N.S. (2006) RCM rainfall for UK flood frequency estimation. II. Climate change results. Journal of Hydrology, 318, 163-172.

Kundzewicz Z.W., Graczyk D., Maurer T., Pińskwar I., Radziejewski M., Svensson C., Szwed M. (2005) Trend detection in river flow series: 1. Annual maximum flow. Hydrological Sciences Journal, 50(5), 797-810.

Kundzewicz Z.W., Radziejewski M., Pińskwar I. (2006) Precipitation extremes in the changing climate of Europe. Climate Research, 31, 51-58.

Lehner B., Döll P., Alcamo J., Henrichs T., Kaspar F. (2006) Estimating the impact of global change on flood and drought risks in Europe: a continental integrated analysis. Climatic Change, 75, 273-299.

López de Lucio R. (2003) Transformaciones territoriales recientes en la región urbana de Madrid. Urban, 8, pp 124-161.

May, W. (2007) The simulation of the variability and extremes of daily precipitation over Europe by the HIRHAM regional climate model, Global Planet. Change, 57, 59-82, doi:10.1016/j.gloplacha.2006.11.026.

Munich Re (2005) Topics Geo - Annual review: Natural catastrophes 2004.

Mudelsee M., Börngen M., Tetzlaff G., Grünewald U. (2003) No upward trends in the occurrence of extreme floods in central Europe. Nature, 425, 166-169.

Nakicenovic, N., and R. Swart (Eds.), (2000) IPCC Special Report on Emission Scenarios, Cambridge Univ. Press, Cambridge, U.K.

Pope, V.D., M.L. Gallani, P.R. Rowntree, and R.A. Stratton (2000) The impact of new physical parameterizations in the Hadley Centre climate model - HadAM3, Climate Dynamics, 16, 123146, doi: $10.1007 / \mathrm{s} 003820050009$.

Reginster I., Rounsevell M. (2006) Scenarios of future urban land use in Europe. Environment and Planning B: Planning and Design, 33, pp 619-63.

Semmler T., Jacob D. (2004) Modeling extreme precipitation events - a climate change simulation for Europe. Global and Planetary Change, 44, 119-127.

van der Knijff, J., Younis J., de Roo A. (2008) LISFLOOD: a GIS-based distributed model for river-basin scale water balance and flood simulation, International Journal of Geographical Information Science, to appear.

White R., Engelen C., Uljee I., Lavalle C., Erlich D. (1999) Developing an Urban Land Use 
Simulator for European Cities. In 5th EC-GIS workshop, Italy: European Communities. 